International Journal of Current Microbiology and Applied Sciences

ISSN: 2319-7706 Volume 6 Number 7 (2017) pp. 607-615

Journal homepage: http://www.ijcmas.com

Original Research Article

https://doi.org/10.20546/ijcmas.2017.607.074

\title{
MAA-Palythine Compound of Three Red (Macro) Algae: Gelidiella acerosa, Acanthophora spicifera and Hypnea musciformis of Gulf of Mannar, Southeast Coast of India
}

\author{
C.M. Ramakritinan ${ }^{1 *}$, K. Durai Kannu ${ }^{1}$, V. Muthuraj ${ }^{2}$ and N. Sornalatha ${ }^{1}$ \\ Department of Marine and Coastal Studies, School of Energy, Environment and Natural \\ Resources, Madurai Kamaraj University, Madurai - 625 021, Tamilnadu, India \\ ${ }^{2}$ Research Department of Chemistry, VHNSN College, Virudhunagar, Tamilnadu, India \\ *Corresponding author
}

A B S T R A C T

Keywords

Gulf of Mannar,

Mycosporine-like

Amino acids,

Palythine, Red

algae, RP-HPLC,

UV-Vis.

Article Info

Accepted:

14 June 2017

Available Online:

10 July 2017
Gulf of Mannar is a unique marine habitat with diverse of macroaglae. They have a rich source of nutrients, biologically active UV absorbing compounds like Mycosporine like Amino acids (MAAs). In this study, red algae Gelidiella acerosa, Acanthophora spicifera and Hypnea musciformis collected from Pudumadam, Gulf of Mannar, southeast coast of India were used for isolation of MAAs. The UV-Vis spectrophotometer analysis of methanol extract of $G$. acerosa, A. spicifera and $H$. musciformis showed an absorption peak at ${ }^{\lambda} \max$ between 309-360nm. Further UV-absorbing compounds were identified using RP-HPLC analysis and the compound identified in all three species of red algae is MAA-Palythine type. This serves as an important role in photoprotectant in the marine environment.

\section{Introduction}

Mycosporine-like amino acids (MAAs), a family of UV-absorbing compounds have recently much consideration because of the photoprotective molecules against UVR in the aquatic organisms (Rastogi et al., 2010; Hartmann et al., 2015). MAAs are small (244-374 Da) and water soluble UVabsorbing molecules in the wavelength range between 310-365 nm (Oren and Cimerman, 2007). These were occurring in marine, freshwater and terrestrial organisms i.e., cyanobacteria, algae, metazoans etc., (Favre Bonvin et al., 1976; Karentz, 2001; Shick and Dunlap, 2002; Sinha et al., 2007; Hartman et al., 2015). The first description and 'baptizing' of Mycosporine refers to sporulating terrestrial fungi (Leach, 1965; Whitehead et al., 2001). MAAs are a family of intracellular compounds biosynthesized by shikimic acid pathway for the synthesis of aromatic amino acids involved in the protection of aquatic organisms against solar radiation (Singh et al., 2010; Bhatia et al., 2011).

More than twenty different MAAs are successfully identified and characterized from various organisms (Whitehead and Hedges, 
2002; Korbee et al., 2010). Organisms exposed to intense solar radiation have been developed a certain mechanisms such as avoidance, repair and protection by synthesizing or accumulating a series of photo-protective compounds such as MAAs, scytonemin, carotenoids and certain other compounds to counteract the toxicity of UV (mainly UVB) radiation (Sommaruga et al., 2006; Sinha et al., 2007; Singh et al., 2008; Klisch and Hader, 2008; Fleming and Castenholz, 2007).

Macroaglae play an important role in the marine ecosystems. They can provide nutrients, agricultural products, pharmaceutical lead compounds, potential bio-fuels and sun screen biomolecules (Gao and McKinley, 1994; Oreon and Cimerman, 2007). Macroaglae have a well-developed mechanism against Ultra Violet Radiation (UVR) damaging effects (Drollet et al., 1997; Rastogi et al., 2010). Macroalgae show more resistance against UV than terrestrial plants (Yuan et al., 2008; Talarico and Maranzana, 2000; Gao and McKinley, 1994; Oreon and Cimerman, 2007).

A known mechanism of protection involves the synthesis of UV absorbing compounds. UVACs have absorption spectra at ${ }^{\lambda} \max$ between 310-360 nm (Nakamura et al., 1982). As photo-protectants, MAAs in the cells absorbs the lethal doses of highly energetic UVR and then dissipating this energy in the form of harmless heat radiation to their surroundings (Oreon and Cimerman, 2007). As nature's sunscreen compounds, MAAs actively excreted and accumulated at the epidermis where they show sunscreening effect. Studies on the photodegradation and photophysical characteristics have shown that MAAs are stable and effective sunscreen (Oreon and Cimerman, 2007). A product 'Helioguard 365' from red algae, Porphyra umbilicalis has been commercialized successfully after a large evaluation and they are also of immense importance for human beings to effectively block thymine dimer formation by UVR in-vitro and to provide growth stimulation activity in human cells (Bandaranayake, 1998; Schulz and Scherer, 1999; Cockell and Knowland, 1999). The other functions of the MAAs are antioxidants, abiotic stressors, intracellular nitrogen storage etc., (Whitehead and Hedges, 2005; Kogej et al., 2006; Shick et al., 1992; Oreon and Cimerman, 2007), as a result, MAAs has varied ecological and therapeutic significance.

The concentration of UVACs is affected by various factors such as light, depth, temperature etc., (Karsten et al., 1998; Korbee et al., 2004). MAA content shows a negative correlation with water depth, but the ability for MAA synthesis in response to environmental changes is varied among algae (Hoyer et al., 2001). MAAs also act as antioxidants, for example, Mycosporineglycine shows a moderate antioxidant potential (Dunlap and Yamamoto, 1995; Oreon and Cimerman, 2007). Many macroaglae produce one or more MAAs. Most of MAAs-producing macroaglae belong to Rhodophyceae (red algae), Phaeophyceae (brown algae) and very few in Chlorophyceae (green algae). Different techniques have been involved in the identification and characterization of MAAs (i.e., UVspectrophotometer, ESI-LC/MS and HPLC analysis) and it is very challenging one (Dunlap and Chalker, 1986; Tartarotti and Sommaruga, 2002; Hartmann et al., 2015). For separation of MAAs, the reversed phase HPLC has been utilized to date (Stochaj et al., 1994; Volkmann and Gorbushina, 2006). Hence the MAAs from macroalgae were separated using RP-HPLC analysis.

Very few reports are available on isolation and identification of Mycosporine like amino acids in marine flora and fauna of Indian 
coastal water (Bhandari and Sharma, 2006). There was an increasing amount of Mycosporine like amino acids in cyanobacteria species isolated from corals Porites sp., and Phormidium corium in Kavarathi reefs of the Lakshadweep islands exposed under UV-B treatment (Bhandari and Sharma, 2010). There was a lack of studies in isolation and identification of MAAs in marine flora and fauna of Gulf of Mannar, except a study done recently by Pandey et al., (2017) and they isolated shinorine, porphyra334 and palythine types of MAAs from both marine red macro algae, Gelidium sp. and Ceramium sp., collected from the west coast (Arabian sea) of India. Therefore the present study was aimed to isolate and separate MAA compounds in G. acerosa, A. spicifera and $H$. musciformis belonging to red algae of Gulf of Mannar, Southeast coast of India.

\section{Materials and Methods}

\section{Collection of samples}

In this study, Red algae (Rhodophyta) such as Gelidiella acerosa (Forsskal) (Feldmann and Hamel, 1934), Acanthophora spicifera (Vahl) (Borgesen 1910) and Hypnea musciformis (Wulfen) (Lamouroux 1813) were collected during March-April, 2012 from the rocky shore at low tide region in Pudumadam (Long N $9^{\circ} 16.313$ Lat E $79^{\circ} 00.073$ ), Gulf of Mannar, Southeast coast of India. The collected samples were immediately rinsed with water to remove all kinds of epiphytes and other impurities. The cleaned samples were immediately kept in sterilized Ziploc bags and transferred to a laboratory for further study.

\section{MAAs extraction}

The samples were allowed to shade dry (up to 7 days) and individually made powder form. The powdered sample of each species (5 to 10 gm each) was individually suspended in
$100 \%$ methanol and kept in horizontal shaker at $25^{\circ} \mathrm{C}$ for 24 hours. The methanol layer was filtered using Whatman No.1 filter paper. The filtered sample was individually centrifuged at $5000 \mathrm{rpm}$ for $10 \mathrm{~min}$ at $4^{\circ} \mathrm{C}$. The supernatant was collected in a separate flask. The residue was extracted at least 2 to 3 times until the solution as colourless. At each centrifugation, the supernatant was pooled and kept separately. Then the extract was concentrated using a rotary vacuum evaporator (Super Fit: PMTC-3040) at $40^{\circ} \mathrm{C}$. The final concentrated crude extract was individually stored in sterile air tight bottles and kept in a refrigerator until use.

\section{UV-Vis Spectrophotometer Analysis}

For the spectral analysis, $1 \mathrm{~mL}$ of crude extract was individually dissolved in methanol $(1: 9, \mathrm{v} / \mathrm{v})$. The individual aliquot was read in the absorbance range between 200 to $600 \mathrm{~nm}$ at regular interval in double beam UV-Vis spectrophotometer (JASCO-V550). The raw spectral data were analysed by UVsolution software (Origin Pro 6, Origin Lab Corp., USA).

\section{RP-HPLC analysis}

For isolation and identification of MAAs from the crude extract, the analysis was carried out using an HPLC system (PR-8 Column, VIVA C8-5 micrometer $250 \times 46 \mathrm{~mm}$ ) equipped with a diode-array detector using isocratic reverse-phase HPLC.

An aliquot of $20 \mu 1$ of the extract was injected into a C8-column protected with RP8 guard column. During analysis, the samples in the auto sampler were kept at $15^{\circ} \mathrm{C}$ (SIL 20AHT) while the column was maintained at $20^{\circ} \mathrm{C}$.

The mobile phase consisted of $20 \%$ aqueous methanol (v/v) and $0.1 \%$ acetic acid (v/v) in water at a flow rate of $0.79 \mathrm{~mL} \mathrm{~min}$. Purification peaks were monitored at $330 \mathrm{~nm}$. 
The compound showing variable peaks were eluted and the identification of the MAA was done by comparing the absorption spectra and retention times of previously published papers.

\section{Results and Discussion}

In this study, the presence of UV absorbing compound in the methanol extract of $G$. acerosa, A. spicifera and $H$. musciformis collected from Pudumadam, Gulf of Mannar Coast was confirmed by UV-Visible spectral analysis and the absorption peaks were obtained in the range between $300 \mathrm{~nm}$ and $360 \mathrm{~nm}$.

Based on this UV- spectral analysis, the MAA peak was observed at ${ }^{\lambda} \max 320 \mathrm{~nm}$ in all three algal samples (Fig. 1). Generally, MAA is abundantly present in macroaglae of tropical/polar regions (Banaszak and Lesser, 1995; Karsten et al., 1998a). The MAAs were abundant in Rhodophyceae (red algae) (Xiong et al., 1999).

The low concentration of (MAAs) palythine, porphyra-334, shinorine, Mycosporineglycine, astesina-330, palythinol and palythenelusujirene like MAA compounds found in Palmaria decipiens, Iridea sp. and Porphyra columbina (Carreto et al., 2005). Based on this statement, the present study was carried out to choosing the macroalgae possess UV absorbing compounds.

Normally the MAAs are detected in white, yellow and blue light regions. Generally the MAA- Palythine compound was exposed in blue light regions at ${ }^{\lambda} \max 320 \mathrm{~nm}$ (Franklin et al., 2001).

Further, the compound was identified using the spectrum obtained from RP-HPLC analysis. The absorbance peak of G. acerosa, A. spicifera and $H$. musciformis were eluted at $\mathrm{R}_{\mathrm{t}}$ (Retention time) of $3.194 \mathrm{~min}, 3.215 \mathrm{~min}$ and $3.198 \mathrm{~min}$, respectively, which exhibited ${ }^{\lambda} \max$ at $320 \mathrm{~nm}$ (Figs. 2 to 4 ). Based on the result of UV-Vis spectrophotometer and RPHPLC analysis, the identified compound was MAA-palythine.

Tsujino et al., (1998) isolated Palythine compound from the aqueous ethanol extract of Chondrus yondoi which is stable under acidic conditions and the structure was confirmed by 1D NMR and IR measurements and the absorption peak appears at $320 \mathrm{~nm}(\varepsilon$ 35,500). Three different types of MAAs such as shinorine $(\lambda \max =333.5 \mathrm{~nm})$, porphyra-334 $(\lambda \max =332.3 \mathrm{~nm})$ and palythine $(\lambda \max =317.9$ $\mathrm{nm})$ having retention times (RT) 1.26, 2.12 and $3.64 \mathrm{~min}$, respectively, from Gelidium sp. and shinorine $(\lambda \max =332.3 \mathrm{~nm})$, porphyra$334(\lambda \max =333.5 \mathrm{~nm})$ and palythinol $(\lambda \max =332.5 \mathrm{~nm})$ with RT $1.27,2.13$ and $4.61 \mathrm{~min}$, respectively, from Ceramium sp., collected from the West Coast (Arabian Sea) of India (Pandey et al., 2017)

The lyophilized methanol extract of Palmaria palmata found high polar MAAs i.e., palythine, shinorine, asterina-330 and porphyra and these compounds were separated and identified with the help of RPHPLC in ${ }^{\lambda} \max 330$ (Yuan et al., 2009; Carignan and Carreto, 2013; Sung-Suk et al., 2014).

Generally the lead MAAs were mostly obtained from UV- stress condition in dinoflagellate (Garcia-Pichel and Castenholz, 1993; Klisch and Hader, 2002; Rosic and Dove, 2011). Similarly, the MAAs and palythine compounds were identified in red alga Bryocladia sp and Chondrus crispus under UV-A radiation (Riegger and Robinson, 1997; Kannaujiya et al., 2014). Similar type of MAA compound was also identified in some Antarctic algae, cyanobacteria (Saman Mushir and Tasneem Fatma, 2011). 
Fig.1 UV-Vis spectrophotometer absorbance of Palythine compound at ${ }^{\lambda} \max$ $320 \mathrm{~nm}$ in methanol extracts of G. acerosa, A. spicifera and H. musciformis

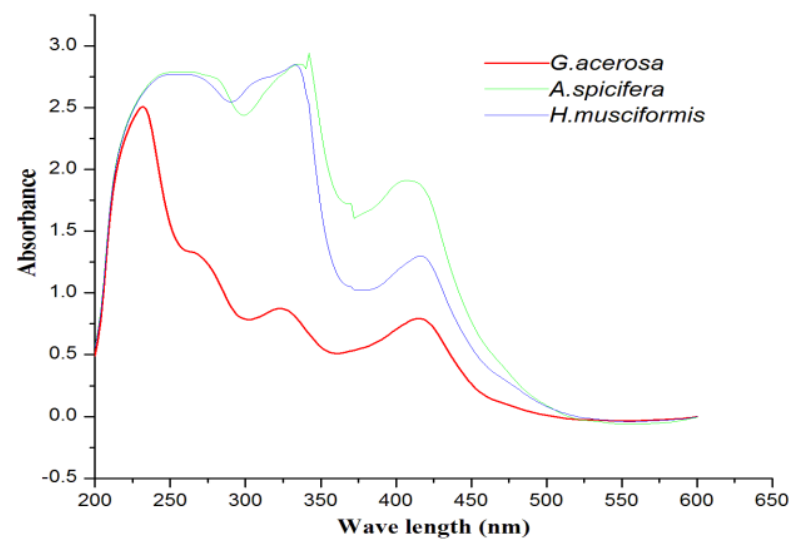

Fig.2 HPLC chromatogram of G. acerosa showing the peak for Palythine compound at $\mathrm{R}_{\mathrm{t}}: 3.194 \mathrm{~min}$

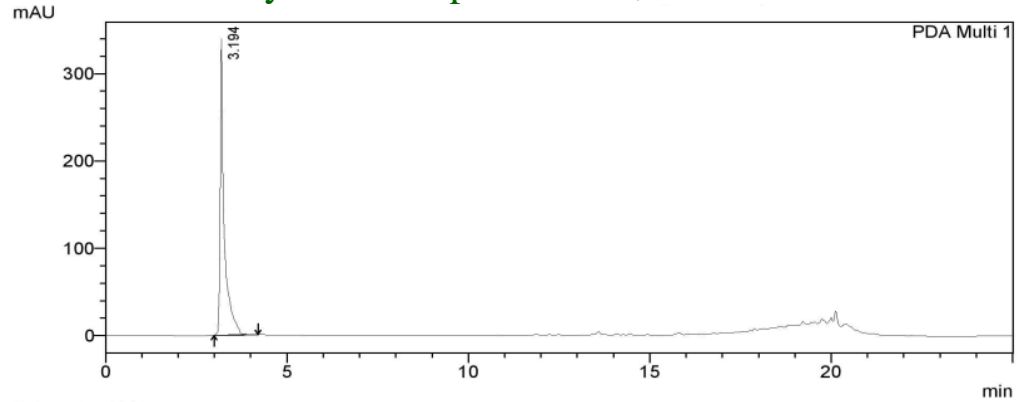

Fig.3 HPLC chromatogram of A. spicifera showing the peak for Palythine compound at $\mathrm{R}_{\mathrm{t}}: 3.215$ min

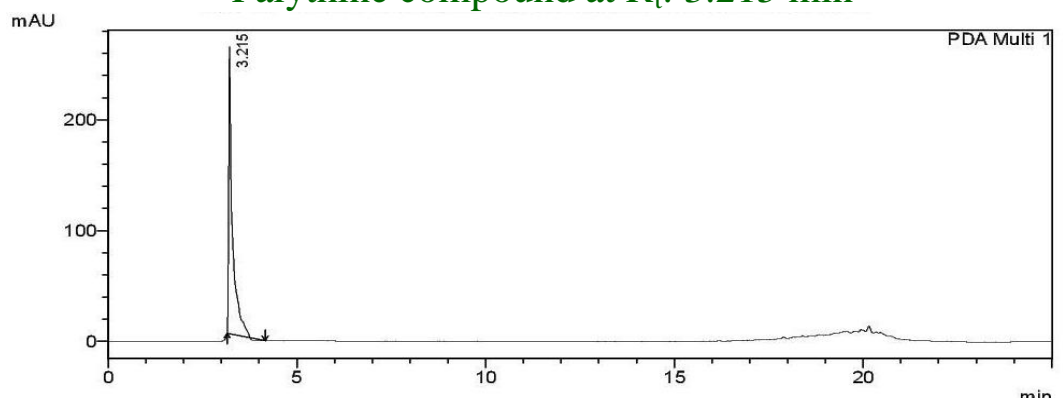

Fig.4 HPLC chromatogram of $H$. musciformis showing the peak for Palythine compound at $\mathrm{R}_{\mathrm{t}}: 3.198 \mathrm{~min}$

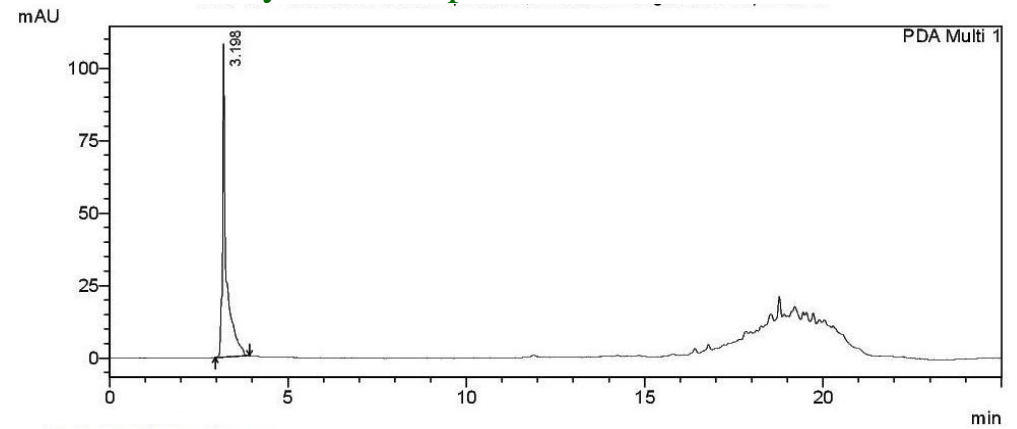


The present investigation on the isolation and identification of MAAs in the methanol extract of $G$. acerosa, A. spicifera and $H$. musciformis confirmed that all three species of red algae have a single type of MAA Palythine compound with absorption peak strongly showed ${ }^{\lambda} \max$ at $320 \mathrm{~nm}$.

The comprehensive results strongly designate that the red algae G. acerosa, A. spicifera and $H$. musciformis of Gulf of Mannar, southeast coast of India found to have a rich source of MAA-Palythine type photoprotective compound.

\section{Acknowledgement}

We sincerely acknowledge the receipt of partial financial support from the Ministry of Environment and Forests, New Delhi to carry out the work for the financial support and the University Grants Commission, New Delhi is also thankfully acknowledged for providing fund in the form of UCG-BSR fellowship to Durai Kannau.

Authors are also thankful to Mr. D. Dineep, Scientist Assistant, M.G. University, Kottayam, Kerala, School of Chemistry for technical support of this study and to the UGC-INFO NET service at Madurai Kamaraj University, Tamilnadu, India for collection on literature.

\section{Conflict of interest statement}

We declare that we have no conflict of interest.

\section{References}

Banaszak, A.T., and Lesser, M.P. 1995. Survey of mycosporine-like amino acids in macrophytes of Kaneohe Bav. In Ultraviolet Radiation and Coral Reefs. Hawaii Institute of Marine Biology Technical Report, (Eds.) D. Gulko and P.
Jokiel, Honolulu: University of Honolulu, 41: 171-179.

Bandaranayake, W.M. 1998. Mycosporines: Are they nature's sunscreens? Nat. Pro. Rep. 15: 159-172.

Bhandari, R. and Sharma, P.K. 2006. Effect of UV-B radiation on photosynthesis, memberane lipids and MAAs in marine Cyanobacteriaum, Phormidium corium (Agardh) Gomont. Indian J. Experiment. Biol., 44: 330-335.

Bhandari, R. and Sharma, P.K. 2010. UV-B radiation and high light induced oxidative damage in Phormidium corium may cause bleaching to associated corals. Indian $\mathrm{J}$. Mar. Sci. 39(3): 423-428.

Bhatia, S., Sharma, K., Namdeo, A.G., Chaugule, B.B., Kavale, M. and Nanda, S. 2010. Broad-spectrum sun-protective action of Porphyra-334 derived from Porphyra vietnamensis. Pharmacog. Res. 2: 45-9.

Bhatia, S., Garg, A., Sharma, K., Kumar, S., Sharma, A. and Purohit, A.P. 2011. Mycosporine and mycosporine-like amino acids: A paramount tool against ultra violet irradiation. Pharmacogn. Rev. 5(10): 138-146.

Carignan, M.O. and Carreto, J.I. 2013. Characterization of mycosporine-serineglycine methyl ester, a major mycosporine-like amino acid from dinoflagellates: a mass spectrometry study. J. Phycol. 49(4): 680-688.

Carreto, J.I., Carignan, M.O. and Montoya, N.G. 2005. A high-resolution reversephase liquid chromatography method for the analysis of mycosporine-like amino acids (MAAs) in marine organisms. Mar. Biol., 146: 237-252.

Cockell, C.S. and Knowland, J. 1999. Ultraviolet radiation screening compounds. Biol. Rev. 74:311-345.

Drollet, J.H., Teai, T., Facon, M. and Martin, P.M.V. 1997. Field study of compensatory changes in the UVabsorbing compounds in the mucus of solitary coral Fungia repanda (Scleractinia: Fungiidae) in relation to 
UV radiation, sea-water temperature and other coincident physicochemical parameters. Mar. Freshwater Res., 48 (4): 329-333.

Dunlap, W.C. and Chalker, B.E. 1986. Identification and quantitation of near-UV absorbing compounds (S-320) in a Hermatypic scleractinian. Coral Reefs, 5: 155-159.

Dunlap, W.C. and Yamamoto, Y. 1995. Smallmolecule antioxidants in marine organisms: antioxidant activity of mycosporine-glycine. Comp. Biochem. Physiol. Part B, 112: 105-114.

Favre-Bonvin, J., Arpin, N. and Brevard, C. 1976. Structure de la mycosporine (P310). Canadian J. Chem., 54: 11051111.

Fleming, E.D and Castenholz, R.W. 2007. Effects of periodic desiccation on the synthesis of the UV-screening compound, scytonemin, in cyanobacteria. Environ. Microbiol. 9:1448-1455

Franklin, L.A., Krabs, G. and Kuhlenkamp, R. 2001. Blue light and UV-A radiation control the synthesis of Mycosporine-like amino acids in Chondrus crispus (Florideophyceae). J. Phycol., 37: 257270.

Gao, K. and McKinley, K.R. 1994. Use of macroalgae for marine biomass production and $\mathrm{CO}_{2}$ remediation: a review. J. Appl. Phycol., 6: 45-60.

Garcia-Pichel, F. and Castenholz, R.W. 1993. Occurrence of UV-absorbing, Mycosporine-like compounds among cyanobacteriail isolates and an estimate of their screening capacity. Appl. Environment. Microbiol, 59: 163-169.

Hoyer, K., Karsten, U., Sawall, T. and Wiencke, C. 2001. Photoprotective substances in Antarctic macroalgae and their variation with respect to depth distribution, different tissues and developmental stages. Mar. Ecol. Prog. Ser., 211: 117-29

Kannaujiya, V., Richa, K. and Sinha, R.P. 2014. Peroxide scavenging potential of ultraviolet-B-absorbing mycosporine-like amino acids isolated from a marine red alga Bryocladia sp. Front. Environment. Sci., $\quad 2(26)$ : $1-8$. doi.org/10.3389/fenvs.2014.00026

Karentz, D. 2001. Chemical defences of marine organisms against solar radiation exposure: UV-absorbing mycosporinelike amino acids and scytonemin. In: Marine Chemical Ecology. (Eds.) J.B. McClintock and B.J. Baker. CRC Press, Boca Raton, FL, USA, Pp: 481-520.

Karsten, U. and Wiencke, C. 1999. Factors controlling the formation of UVabsorbing mycosporine-like amino acids in the marine red alga Palmaria palmata from Spitsbergen (Norway). J. Plant Physiol., 155: 407-15.

Karsten, U., Franklin, L.A., Luning, K. andWiencke, C. 1998. Natural ultraviolet radiation and photosynthetically active radiation induce formation of mycosporine-like amino acids in the marine macroalga Chondrus crispus (Rhodophyta). Planta, 205: 257-62.

Karsten, U., Sawall, T. and Wienske, C. 1998. A survey of the distribution of UVabsorbing substances in tropical macroaglae. Phycolog. Research, 46: 271279.

Klisch, M. and Hader, D.P. 2008. Mycosporinelike amino acids and marine toxins-the common and the different. Mar. Drugs 6:147-163.

Klisch, M. and Hader, D.P. 2002. Wavelength dependence of Mycosporine-like amino acid synthesis in Gyrodinium dorsum. J. Photochem. Photobiol. B: Biology, 66: 60-66.

Kogej, T., Gostincar, C., Volkmann, M., Gorbushina, A.A. and Cimerman, G.N. 2006. Mycosporines in extremophilic fungi: Novel complementary osmolytes? Environ. Chem. 3:105-110.

Korbee, P.N., Mata, M.T. and Figueroa, F.L. 2010. Photo-protection mechanisms against ultraviolet radiation in Heterocapsa sp. (Dinophyceae) are influenced by nitrogen availability: mycosporine-like amino acids vs. xanthophyll cycle. Limnol. Oceanog, 
55:899-908

Korbee, P.N., Diaz, R.T.A. and Figueroa, F.L. 2004. Ammonium and UV radiation stimulate the accumulation of mycosporine-like amino acids in Porphyra columbina (Rhodophyta) from Patagonia, Argentina. J. Phycol., 40: 24859.

Laurion, I., Lami, A. and Sommaruga, R. 2002. Distribution of mycosporine-like amino acids and photoprotective carotenoids among freshwater phytoplankton assemblages. Aquatic Microbial Ecol., 26: 283-294.

Leach, C.M. 1965. Ultraviolet-absorbing substances associated with light-induced sporulation in fungi. Canadian J. Bot., 43: 185-200.

Nakamura, H., Kobayashi, J. and Hirata, Y. 1982. Separation of Mycosporine like amino acids in marine organisms using reversed-phase high-performance liquid chromatography. J. Chromatograph., 250: 113-8.

Oren, A. and Cimerman, G.N. 2007. Mycosporines and mycosporine- like amino acids: UV protectants or multipurpose secondary metabolites? FEMS Microbiol. Letters, 269: 1-10.

Pandey,A., Pandey, S., Rajneesh, Pathak, J., Ahmed, H., Vidya Singh, Shailendra, P. Singh and Sinha, R.P. 2017. Mycosporine-Like Amino Acids (MAAs) Profile of Two Marine Red Macroalgae, Gelidium sp. and Ceramium sp. Int. J. Appl. Sci. Biotechnol. 5(1): 12-21

Rastogi, R., Richa, P., Singh, S.P., Häder, D.P. and Sinha, R.P. 2010. Mycosporine-like amino acids profile and their activity under PAR and UVR in a hot-spring cyanobacterium Scytonema sp. HKAR-3. Australian J. Bot., 58:286-293

Riegger, L. And Robinson, D. 1997. Photoinduction of UV-absorbing compounds in Antarctic diatoms and Phaeocystis Antarctica. Mar. Ecol. Prog. Ser., 160: 13-25.

Rosic, N.N. and Dove, S. 2011. MycosporineLike Amino Acids from Coral
Dinoflagellates. Appl. Environ.

Microbiol, 77(24): 8478-8486. doi: 10.1128/AEM.05870-11

Saman Mushir and Tasneem Fatma. 2011. Ultraviolet radiation absorbing Mycosporine-like amino acids in cyanobacterium Aulosira fertilissima: Environment. Perspect. Characteriza. Curr. Res. J. Biolog. Sci., 3 (2): 165-171.

Schulz, M.E. and Scherer, S. 1999. UV protection in cyanobacteria. Eur. J. Phycol. 34:329-338.

Shick, J.M., Walter, C.B., Chalker, E., Banaszak, A.T. and Osenzwei, T.K. 1992. Survey of ultraviolet radiation-absorbing mycosporine-like amino acids in organs of coral reef holothuroids. Mar. Ecol. Prog. Ser. 90:139-148.

Shick, J.M. and Dunlap, W.C. 2002. Mycosporine-like amino acids and related gadusols: biosynthesis, accumulation, and UV protective functions in aquatic organisms. Annu. Rev. Physiol., 64: 223262.

Singh, S.P., Kumari, S., Rastogi, R.P., Singh, K.L. and Sinha, R.P. 2008. Mycosporinelike amino acids (MAAs): chemical structure, biosynthesis and significance as UV-absorbing/screening compounds. Ind. J. Exp. Biol. 46:7-17

Sinha, R.P., Singh, S.P. and Hader, D.P. 2007. Database on mycosporines and mycosporine-like amino acids (MAAs) in fungi, cyanobacteria, macroalgae, phytoplankton and animals. J. Photochem. Photobiol. B: Biology 89:2935

Sommaruga, R., Whitehead, K., Shick, J.M. and Lobban, C.S. 2006. Mycosporine-like amino acids in the zooxanthella-ciliate symbiosis Maristentor dinoferus. Protist 157:185-191

Sommaruga, R. and Garcia-Pichel, F. 1999. UV-absorbing compounds, in planktonic and benthic organisms from a highmountain lake. Archiv fur Hydrobiologie, 144: 225-269.

Stochaj, W.R., Dunlap, W.C. and Shick, J.M. 1994. Two new UV-absorbing 
mycosporine-like amino-acids from the sea-anemone Anthopleura elegantissima and the effects of zooxanthellae and spectral irradiance on chemical composition and content. Mar. Biol. 118, 149-156.

Sung-Suk, S., Wang, J.H., Park, M., Seo, H.H., Kim, H.S., Lee, J.H., Moh, S.H. and Lee, T.K. 2014. Anti-Inflammation Activities of Mycosporine-Like Amino Acids (MAAs) in Response to UV Radiation Suggest Potential Anti-Skin Aging Activity. Mar. Drugs, 12(10): 5174-5187. doi: $10.3390 / \mathrm{md} 12105174$

Talarico, L. and Maranzana, G. 2000. Light and adaptive responses in red macroalgae: An overview. J. Photochem. Photobiol. Biol. $56: 1-11$.

Tartarotti, B. and Sommaruga, R. 2002. The effect of different methanol concentrations and temperatures on the extraction of Mycosporine-like amino acids (MAAs) in algae and zooplankton. Archiv fur Hydrobiologie, 154: 691-703.

Tsujino, I., Yabe, K., Sekikawa, I. and Hamanaka, N. 1978. Isolation and structure of a mycosporine from the red alga Chondrus yendoi. Tetrahedron Lett. 19, 1401-1402.
Volkmann, M. and Gorbushina, A.A. 2006. A broadly applicable method for extraction and characterization of mycosporines and mycosporine-like amino acids of terrestrial, marine and freshwater origin. FEMS Microbiol. Lett. 255, 286-295.

Whitehead, K. and Hedges, J.I. 2005. Photodegradation and photosensitization of mycosporine-like amino acids. J. Photochem. Photobiol. Biol. 80:115-121.

Whitehead, K. and Hedges, J.I. 2002. Analysis of mycosporine-like amino acids in plankton by liquid chromatography electrospray ionization mass spectrometry. Mar. Chem., 80: 27-39.

Whitehead, K. Gorbushina, A.A. and Hedges, J.I. 2001. Mycosporines in the environment: their analysis and implications. In: American Chemical Society, Annual Meeting, April 2001, San Diego, USA.

Yuan, Y.V. Westcott, N.D. Hu, C. and Kitts, D.D. 2009. Mycosporine-like amino acid composition of the edible red alga, Palmaria palmate (Dulse) harvested from the west and east coasts of Grand Manan Island, New Brunswick. Food Chemistry, 112: 321-328.

\section{How to cite this article:}

Ramakritinan, C.M., K. Durai Kannu, V. Muthuraj and Sornalatha, N. 2017. MAA-Palythine Compound of Three Red (Macro) Algae: Gelidiella acerosa, Acanthophora spicifera and Hypnea musciformis of Gulf of Mannar, Southeast Coast of India. Int.J.Curr.Microbiol.App.Sci. 6(7): 607-615. doi: https://doi.org/10.20546/ijcmas.2017.607.074 